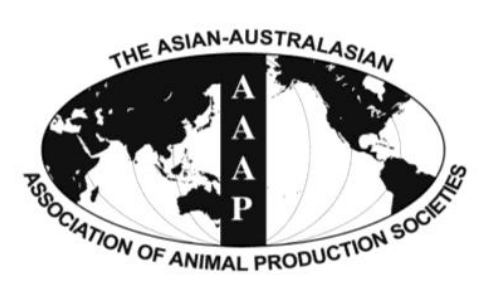

Open Access

Asian Australas. J. Anim. Sci.

Vol. 27, No. 8 : 1088-1097 August 2014

http://dx.doi.org/10.5713/ajas.2013.13714

www.ajas.info

pISSN 1011-2367 elSSN 1976-5517

\title{
Effect of Gynosaponin on Rumen In vitro Methanogenesis under Different Forage-Concentrate Ratios
}

\author{
Bakhetgul Manatbay, Yanfen Cheng, Shengyong Mao, and Weiyun Zhu* \\ Laboratory of Gastrointestinal Microbiology, Nanjing Agricultural University, Nanjing 210095, China
}

\begin{abstract}
The study aimed to investigate the effects of gynosaponin on in vitro methanogenesis under different forage-concentrate ratios ( $\mathrm{F}: \mathrm{C}$ ratios). Experiment was conducted with two kinds of $\mathrm{F}: \mathrm{C}$ ratios $(\mathrm{F}: \mathrm{C}=7: 3$ and $\mathrm{F}: \mathrm{C}=3: 7)$ and gynosaponin addition $(0 \mathrm{mg}$ and $16 \mathrm{mg}$ ) in a $2 \times 2$ double factorial design. In the presence of gynosaponin, methane production and acetate concentration were significantly decreased, whereas concentration of propionate tended to be increased resulting in a significant reduction $(\mathrm{p}<0.05)$ of acetate:propionate ratio (A:P ratio), in high-forage substrate. Gynosaponin treatment increased $(\mathrm{p}<0.05)$ the butyrate concentration in both F:C ratios. Denaturing gradient gel electrophoresis (DGGE) analysis showed there was no apparent shift in the composition of total bacteria, protozoa and methanogens after treated by gynosaponin under both F:C ratios. The real-time polymerase chain reaction (PCR) analysis indicated that variable F:C ratios significantly affected the abundances of Fibrobacter succinogenes, Rumninococcus flavefaciens, total fungi and counts of protozoa ( $\mathrm{p}<0.05)$, but did not affect the $m c r$ A gene copies of methanogens and abundance of total bacteria. Counts of protozoa and abundance of F.succinogenes were decreased significantly ( $<<0.05)$, whereas mcrA gene copies of methanogens were decreased slightly $(\mathrm{p}<0.10)$ in high-forage substrate after treated by gynosaponin. However, gynosaponin treatment under high-concentrate level did not affect the methanogenesis, fermentation characteristics and tested microbes. Accordingly, overall results suggested that gynosaponin supplementation reduced the in vitro methanogenesis and improved rumen fermentation under highforage condition by changing the abundances of related rumen microbes. (Key Words: Forage:Concentrate Ratios, Gynosaponin, Methanogenesis, Microbiota, In vitro)
\end{abstract}

\section{INTRODUCTION}

Due to the increased concerns of greenhouse gas emissions and the restriction on the use of the antibiotics in the livestock industry, secondary plant metabolites have received noticeable attention as alternative feed additives to modify the rumen microbial ecosystem and suppress enteric methane emission. Saponins are naturally occurring surface-active glycosides, found in various plants in different forms and structures (Vincken et al., 2007). A great many of studies have been conducted to investigate the effects of different saponins on rumen microbial fermentation characteristics and methanogenesis (Lila et al., 2003; Wina et al., 2005; Guo et al., 2008; Pen et al., 2008). However, the results varied depending on the types, doses

\footnotetext{
* Corresponding Author: Weiyun Zhu. Tel: +86-25-84395523, Fax: +86-25-84395314, E-mail: zhuweiyun@ njau.edu.cn

Submitted Nov. 12, 2013; Revised Dec. 30, 2013; Accepted Feb. 2, 2014
}

and structures of saponins, because saponins have different biological activities according to their aglycone portion and combined sugar body of the structure (Hassan et al., 2010). For example, $0.4 \mathrm{~g}$ tea saponins (60\% saponins) and $7.01 \mathrm{~g}$ Yucca schidigera extract (8\% to $10 \%$ saponins) in $1 \mathrm{~L}$ culture medium reduced the protozoa numbers by $16.4 \%$ and $55.9 \%$ and methane production by $14.3 \%$ and $41.7 \%$ respectively (Hu et al., 2005; Pen et al., 2006), whereas 6.91 g Quillaja saponaria extract (5\% to 7\% saponins) and 0.29 $\mathrm{g}$ fenugreek seeds (34\% saponins) in $1 \mathrm{~L}$ culture medium did not affect the methane production (Pen et al., 2006; Goel et al., 2008a).

Researches have also showed that the effectiveness of saponins on methanogenesis was different depending on the composition of diets. For example, Goel et al. (2008a) noted that methane suppressing effects of saponins from Sesbenia sesban and fenugreek were profound in concentrate-based diets compared with roughage based diets. But, Patra et al. (2006) observed that saponins

Copyright @ 2014 by Asian-Australasian Journal of Animal Sciences This is an open-access article distributed under the terms of the Creative Commons Attribution Non-Commercial License (http://creativecommons.org/licenses/by-nc/3.0/), which permits unrestricted non-commercial use, distribution, and reproduction in any medium, provided the original work is properly cited. 
extracted from Acacia concinna did not affect methane production in 1:1 concentrate to roughage based diet.

Gynostemma pentaphyllum Makino, a perennial creeping herb grown prevalently throughout China, India, Japan and Korea (Blumer and Liu, 1999), is a traditional medicine widely used in the treatment of respiratory inflammation such as cough and chronic bronchitis (Tanner et al., 1999). Its medicinal properties have been mainly attributed to the dammarane saponins with $75 \%$ being gynosaponin (Kuwahara et al., 1989). As compared with other saponins, gynosaponin has a high saponin content $(>98 \%)$ and has been showed effective on methane production, fermentation characteristics and cell numbers in fungus-methanogen co-cultures (Wang et al., 2011). However, the effect of gynosaponin on rumen methane production in a rumen system is not known. Thus, the objective of the present in vitro study was, therefore, to evaluate the effects of gynosaponin addition on rumen methanogenesis, fermentation characteristics and microbiota under different forage-concentrate $(\mathrm{F}: \mathrm{C})$ ratios.

\section{MATERIALS AND METHODS}

\section{Animals and inocula}

Three rumen fistulated Nanjing local goats were used for inoculum donor animals. Animals were cared for in accordance with guidelines established by the Chinese Science and Technology Committee Experimental Animal Care and Use guidelines (1998) and the diet was formulated to meet the maintenance requirement (NY/Y 816-2004; Ministry of Agriculture of China, 2004), which included $70 \%$ forage (Chinese wildrye) and $30 \%$ concentrate mixtures $(20 \%$ ground corn, $7 \%$ soybean meal, $1.5 \%$ calcium hydrogen phosphate, $0.5 \%$ stone powder, $0.5 \%$ sodium chloride, and $0.5 \%$ mineral and vitamin premix). Feed was given in equal portions twice daily at 08:00 and 17:00 and the animals had free access to the drinking water. On the day of experiment, rumen contents were collected from three goats just before the morning feeding $(0 \mathrm{~h})$ and immediately homogenized and squeezed through two layers of cheesecloth and poured into insulated flasks under anaerobic conditions as described by Zhu et al. (1999) and used as inocula.

\section{Experimental design}

Experiment was conducted in a $2 \times 2$ double factorial design with substrates Chinese wild rye and concentrate mixture milled to pass through $0.9 \mathrm{~mm}$ sieve. The gynosaponin powder, dammarane type triterpene saponin with $98 \%$ purity, was from Nanjing Zelang Medical Co. Ltd (China). The culture medium was prepared according to Mao et al. (2007a) using Medium D as defined by Longland et al. (1995). Briefly, micromineral solution $0.1 \mathrm{~mL}$, buffer solution $200 \mathrm{~mL}$, macromineral solution $200 \mathrm{~mL}$, resazurin solution $1 \mathrm{~mL}$ and L-cysteine hydrochloride $1 \mathrm{~g}$.

Rumen inocula described above was anaerobically mixed with culture medium, and $60 \mathrm{~mL}$ of buffered rumen fluid was then transferred to $160 \mathrm{~mL}$ capacity serum bottles that contained $0.6 \mathrm{~g}$ total substrate in 7:3 (0.42 $\mathrm{g}$ Chinese wild rye, $0.12 \mathrm{~g}$ ground corn and $0.06 \mathrm{~g}$ soybean meal) and $3: 7$ ( $0.18 \mathrm{~g}$ Chinese wild rye, $0.28 \mathrm{~g}$ ground corn and $0.14 \mathrm{~g}$ soybean meal) ratios and with gynosaponin $(0 \mathrm{mg}$ and 16 $\mathrm{mg}$ ). The addition level of gynosaponin was based on previous researches (Hu et al., 2005; Guo et al., 2008; Wang et al., 2011) and the set of serum bottles without gynosaponin was served as control. Each set had four replicates. The serum bottles were sealed with rubber stoppers and aluminum caps and incubated at $39^{\circ} \mathrm{C}$ for $48 \mathrm{~h}$.

\section{Analytical procedures}

Gas and fermentation characteristics: Total gas production was measured at 2, 4, 8, 12, 24, 36, and $48 \mathrm{~h}$ of incubation time using a pressure transducer and calibrated syringe (Theodorou et al., 1994). After the total gas measurement, methane production was determined using capillary column gas chromatograph (GC-14B, Shimadzu, Japan), with details as described by Wang et al. (2011). The amount of methane was calculated using standard curves (eight points with triplicate estimations; $\mathrm{R}^{2}$ coefficients of 0.994). After $48 \mathrm{~h}$ incubation, the fermentation was terminated by swirling the bottles on ice and the bottles were opened and the $\mathrm{pH}$ of rumen samples was determined immediately using a $\mathrm{pH}$ meter (Ecoscan $\mathrm{pH} 5$, Singapore), and then the content samples were homogenized and subpackaged to $5 \mathrm{~mL}$ centrifuge tubes for further analyses of fermentation characteristics and microbiota. A portion of $5 \mathrm{~mL}$ samples was mixed with freshly prepared $25 \%$ metaphosphoric acid for measuring the volatile fatty acids (VFAs) concentrations using a capillary column gas chromatograph (GC-14B, Shimadzu, Japan), with details as described by Mao et al. (2007a). A portion of $5 \mathrm{~mL}$ samples was acidified with $0.5 \mathrm{~mL} 0.5 \mathrm{~mol} / \mathrm{L} \mathrm{HCl}$ and stored at $-20^{\circ} \mathrm{C}$ for further analysis of $\mathrm{NH}_{3}-\mathrm{N}$ concentration by the indophenols method described by the (Weatherburn, 1967). An aliquot of $5 \mathrm{~mL}$ of samples was kept at $-20^{\circ} \mathrm{C}$ for analysis of ruminal microbial crude protein (MCP) concentrations using a colorimetric method, with $1 \mathrm{mg} / \mathrm{mL}$ bovine serum albumin solution (Sigma-Aldrich Co. LLC, St. Louis, Missouri, USA) as a standard equivalent, described by Makkar et al. (1982).

DNA extraction: Total DNA was extracted from culture samples according to the method of Denman and McSweeney (2006). Briefly, cetyltrimethyl ammonium bromide buffer was used and followed by PhenolChloroform- Isoamyl alcohol extraction (Zhu et al., 2003) and by using equipment FastPrep-24 (MP Biomedical, 
South Florida, USA) and thermomixer compact.

Microbial communities: Rumen microbial communities were revealed by polymerase chain reaction-denaturing gradient gel electrophoresis (PCR-DGGE) technique. Primers used to amplify total bacteria, methanogens and protozoa are shown in Table 1. The PCR was performed using a Taq DNA polymerase Kit (Progma, Madison WI, USA) in a thermocycler (Biometra, Göttingen, Germany). PCR program for bacteria was: $94^{\circ} \mathrm{C}$ for $5 \mathrm{~min}$, and 35 cycles of $94^{\circ} \mathrm{C}$ for $30 \mathrm{~s}, 56^{\circ} \mathrm{C}$ for $20 \mathrm{~s}, 68^{\circ} \mathrm{C}$ for $40 \mathrm{~s}$, and $68^{\circ} \mathrm{C}$ for $7 \mathrm{~min}$ last extension; for methanogens was: $94^{\circ} \mathrm{C}$ for $1 \mathrm{~min} ; 94^{\circ} \mathrm{C}$ for $30 \mathrm{~s}, 58^{\circ} \mathrm{C}$ to $53^{\circ} \mathrm{C}\left(0.5^{\circ} \mathrm{C} /\right.$ cycle $), 72^{\circ} \mathrm{C}$ for $1 \mathrm{~min} 10$ cycles, $94^{\circ} \mathrm{C}$ for $30 \mathrm{~s}, 56^{\circ} \mathrm{C}$ for $30 \mathrm{~s}$ and $72^{\circ} \mathrm{C}$ for 1 min 25 cycles, $72^{\circ} \mathrm{C}$ for 15 min last extension; and for protozoa was: $94^{\circ} \mathrm{C}$ for $4 \mathrm{~min}, 56^{\circ} \mathrm{C}$ for $30 \mathrm{~s}, 72^{\circ} \mathrm{C}$ for 1 min, 35 cycles of $\left(56^{\circ} \mathrm{C}\right.$ for $30 \mathrm{~s}, 94^{\circ} \mathrm{C}$ for $1 \mathrm{~min}$ and $72^{\circ} \mathrm{C}$ for $1 \mathrm{~min}$ ), $94^{\circ} \mathrm{C}$ for $4 \mathrm{~min} ; 56^{\circ} \mathrm{C}$ for $30 \mathrm{~s}$ and $72^{\circ} \mathrm{C}$ for 10 min last extension. After checking the sizes and amounts of amplicons using electrophoresis on $1.2 \%$ agarose gel containing GoldView, DGGE was performed using a Dcode DGGE system (Bio-Rad, Hercules, California, USA) in $8 \%$ polyacrylamide gels containing 37.5:1 acrylamidebiacrylamide and denaturing gradients of $38 \%$ to $53 \%, 40 \%$ to $55 \%$ and $28 \%$ to $43 \%$ of urea for bacteria, methanognes and protozoa respectively (Muyzer et al., 1993; Sylvester et al., 2005; Yu et al., 2008). Running progress of electrophoresis, staining, scanning and analyzing the gel electrophoresis profiles were performed by the method as described by Mao et al. (2007b).

Microbial abundances: Samples for protozoa counting were mixed with $9 \%$ formaldehyde and preserved at $-4^{\circ} \mathrm{C}$, then counted in a haemacytometer under light microscope (Nikon YS100, Nikon, Yokohama, Japan) using the method of Dehority (2005). Group-specific primers for methanogens $(m c r A)$, total bacteria and anaerobic fungi, and species-specific primers for $R$. flavefaciens and $F$. succinogenes are listed in Table 1, as described by Denman and McSweeney (2006) and Denman et al. (2007). Species of Methanobrevibacter sp. (from CSIRO Livestock Industries, St. Lucia, QLD, Australia), rumen anaerobic fungi isolated from rumen contents by Cheng et al. (2006) and $R$. flavefaciens and $F$. succinogenes (from Aberystwyth University, UK) were used to generate standards for realtime PCR analysis. Conventional PCR was performed for respective species and PCR products were quantified using a Nanodrop spectrophotometer ND-1000 UV-Vis (Thermo Fisher Scientific, Inc., Madison, WI, USA). For each standard, copy number concentration was calculated based on the PCR fragment length and the DNA concentration. Real-time quantitative PCR was performed using the ABI 7300 real-time PCR system (Applied Biosystems, Foster, California, USA). Reaction mixture, amplification conditions and performing progresses were conducted by the method of Yang et al. (2012).

\section{Calculation and statistical analysis}

Initially, all data were calculated by Microsoft excel software and statistical analysis was carried out using General Linear Model (univariate) procedure of SPSS (version16.0; SPSS Inst. Inc. Cary, NC, USA). When there were statistical changes on the interaction values of treatments, Tukey in the statistical software package SPSS

Table 1. Primers used for DGGE and Real-time PCR

\begin{tabular}{|c|c|c|c|c|}
\hline Target organisms & Primers & Sequence $\left(5^{\prime} \rightarrow 3^{\prime}\right)$ & $\begin{array}{l}\text { Amplicon } \\
\text { (bp) }\end{array}$ & Reference \\
\hline \multirow[t]{2}{*}{ Total bacteria } & 968F-GC & AACGCGAAGAACCTTAC & 433 & Nübel et al. (1996) \\
\hline & $1401 \mathrm{R}$ & CGGTGTGTACAAGACCC & & \\
\hline \multirow[t]{2}{*}{ Methanogens } & $344 \mathrm{~F}-\mathrm{GC}$ & ACGGGGYGCAGCAGGCGCGA & 175 & Yu ZT et al. (2008) \\
\hline & $519 \mathrm{R}$ & GWATTACCGCGGCKGCTG & & \\
\hline \multirow[t]{2}{*}{ Protozoa } & $316 \mathrm{~F}$ & GCTTTCGWTGGTAGTGTATT & 223 & Sylvester et al. (2005) \\
\hline & 539R-GC & ACTTGCCCTCYAATCGTWCT & & \\
\hline \multirow[t]{2}{*}{ Methanogens } & Forward & TTCGGTGGATCDCARAGRGC & 140 & Denman et al. (2007) \\
\hline & Reverse & GBARGTCGWAWCCGTAGAATCC & & \\
\hline \multirow{2}{*}{ Total bacteria } & Forward & CGGCAACGAGCGCAACCC & 130 & Denman and McSweeny (2006) \\
\hline & Reverse & CCATTGTAGCACGTGTGTAGCC & & \\
\hline \multirow[t]{2}{*}{ Fungi } & Forward & GAGGAAGTAAAAGTCGTAACAAGGTTTC & 120 & Denman and McSweeny (2006) \\
\hline & Reverse & CAAATTCACAAAGGGTAGGATGATT & & \\
\hline \multirow[t]{2}{*}{ R. flavefaciens } & Forward & CGAACGGAGATAATTTGAGTTTACTTAGG & 132 & Denman et al. (2007) \\
\hline & Reverse & CGGTCTCTGTATGTTATGAGGTATTACC & & \\
\hline \multirow[t]{2}{*}{ F. succinogenes } & Forward & GTTCGGAATTACTGGGCGTAAA & 121 & Denman and McSweeny (2006) \\
\hline & Reverse & CGCCTGCCCCTGAACTATC & & \\
\hline
\end{tabular}

DGGE, denaturing gradient gel electrophoresis; PCR, polymerase chain reaction.

GC clamp (40 bp) attached to the Primer (CGCCCGGGGCGCGCCCCGGGCGGGGCGGGGGCACGGGGGG). 

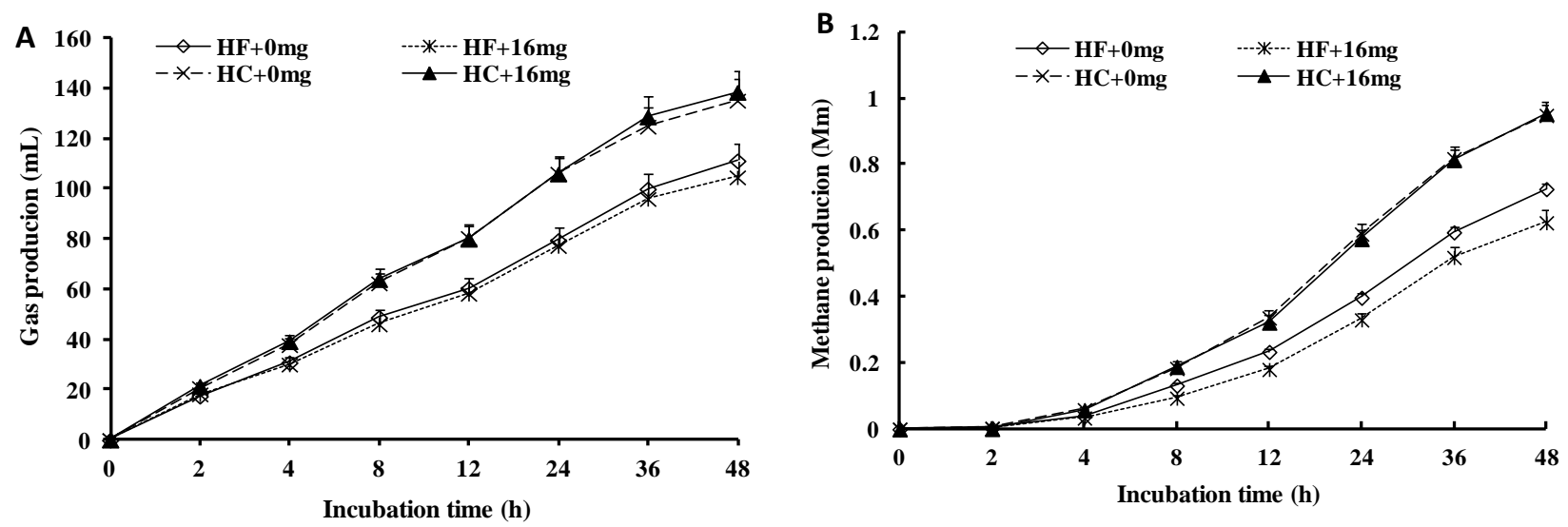

Figure 1. Curves of cumulative gas production (A) and methane production $(\mathrm{B})$. HF+0 $\mathrm{mg}=$ high forage $(\mathrm{F}: \mathrm{C}=70: 30)+0 \mathrm{mg}$ gynosaponin; $\mathrm{HF}+16 \mathrm{mg}=$ high-forage $(\mathrm{F}: \mathrm{C}=70: 30)+16 \mathrm{mg}$ gynosaponin; HC+0 $\mathrm{mg}=$ High-concentrate $(\mathrm{F}: \mathrm{C}=30: 70)+0 \mathrm{mg}$ gynosaponin; $\mathrm{HC}+16 \mathrm{mg}=$ high concentrate $(\mathrm{F}: \mathrm{C}=30: 70)+16 \mathrm{mg}$ gynosaponin. Values presented are the average of the replicate cultures $(n=4)$. Error bars represent the standard error of the mean.

16.0 was used for further analysis of multiple comparisons of individual treatments.

\section{RESULTS}

\section{Total gas, methane production and rumen fermentation} characteristics

The cumulative production of total gas and methane during each measuring point are shown in Figure 1A and 1B. The total gas production and methane production showed a similar increasing pattern. However, the total gas production with high-concentrate substrate showed a relatively faster increasing curve than that with high-forage substrate. There was no difference between gyposaponin treatment and the control on cumulative gas production and methane production at each measuring point under highconcentrate substrates. Gynosaponin addition apparently reduced the total gas and methane production from the $4 \mathrm{~h}$ of incubation in high-forage substrate. This effect was evident (Table 2) during the $48 \mathrm{~h}$ fermentation process, both total gas and methane production of high-concentrate substrate were significantly greater than those of the highforage substrate. Changes in methane production through gynosaponin treatment were $\mathrm{F}: \mathrm{C}$ ratio dependent where gynosaponin addition reduced the cumulative methane production by $14.49 \%(\mathrm{p}<0.05)$ in the high-forage substrate after $48 \mathrm{~h}$ fermentation, while no changes were observed in high-concentrate level.

The effects of $\mathrm{F}: \mathrm{C}$ ratio and gynosaponin treatment on fermentation characteristics are also shown in Table 2. As

Table 2. Effects of gynosaponin on in vitro rumen $48 \mathrm{~h}$ fermentation characteristics at different F:C ratios

\begin{tabular}{|c|c|c|c|c|c|c|c|c|}
\hline \multirow{2}{*}{ Item } & \multicolumn{4}{|c|}{ Treatment $^{1}$ (mg gynosaponin) } & \multirow{2}{*}{ SEM } & \multicolumn{3}{|c|}{ p-value ${ }^{2}$} \\
\hline & $\mathrm{HF}+0$ & $\mathrm{HF}+16$ & $\mathrm{HC}+0$ & $\mathrm{HC}+16$ & & $\mathrm{~F}: \mathrm{C}$ & GS & $\mathrm{F}: \mathrm{C} \times \mathrm{GS}$ \\
\hline Gas production $(\mathrm{mL})$ & $111.34^{\mathrm{a}}$ & $104.76^{\mathrm{b}}$ & $135.34^{\mathrm{c}}$ & $134.64^{\mathrm{c}}$ & 1.80 & $<0.01$ & 0.05 & 0.15 \\
\hline Methane (mmol) & $0.727^{\mathrm{a}}$ & $0.625^{\mathrm{b}}$ & $0.950^{\mathrm{c}}$ & $0.954^{\mathrm{c}}$ & 0.019 & $<0.01$ & 0.02 & $<0.01$ \\
\hline $\mathrm{pH}$ value & $6.54^{\mathrm{a}}$ & $6.59^{\mathrm{b}}$ & $6.36^{\mathrm{c}}$ & $6.40^{\mathrm{d}}$ & 0.01 & $<0.01$ & 0.01 & 0.25 \\
\hline $\mathrm{MCP}(\mathrm{mg} / \mathrm{mL})$ & 0.32 & 0.32 & 0.31 & 0.30 & 0.00 & $<0.01$ & 0.13 & 0.10 \\
\hline $\mathrm{NH}_{3}-\mathrm{N}(\mathrm{mmol} / \mathrm{L})$ & $12.39^{\mathrm{a}}$ & $13.23^{\mathrm{a}}$ & $16.27^{\mathrm{b}}$ & $16.77^{\mathrm{b}}$ & 0.98 & $<0.01$ & 0.51 & 0.86 \\
\hline TVFA (mmol/L) & $74.65^{\mathrm{a}}$ & $72.43^{\mathrm{a}}$ & $88.81^{\mathrm{b}}$ & $91.50^{\mathrm{b}}$ & 1.74 & $<0.01$ & 0.90 & 0.18 \\
\hline Acetate $(\mathrm{mmol} / \mathrm{L})$ & $46.54^{\mathrm{a}}$ & $41.11^{\mathrm{b}}$ & $50.37^{\mathrm{c}}$ & $51.40^{\mathrm{c}}$ & 1.12 & $<0.01$ & 0.02 & 0.01 \\
\hline Propionate (mmol/L) & $12.71^{\mathrm{a}}$ & $13.75^{\mathrm{b}}$ & $14.32^{\mathrm{bc}}$ & $14.7^{\mathrm{c}}$ & 0.45 & 0.01 & 0.14 & 0.48 \\
\hline Butyrate $(\mathrm{mmol} / \mathrm{L})$ & $7.91^{\mathrm{a}}$ & $9.72^{\mathrm{b}}$ & $13.70^{\mathrm{c}}$ & $15.12^{\mathrm{c}}$ & 0.57 & $<0.01$ & 0.04 & 0.74 \\
\hline Valerate $(\mathrm{mmol} / \mathrm{L})$ & $1.97^{\mathrm{a}}$ & $2.05^{\mathrm{a}}$ & $3.38^{\mathrm{b}}$ & $2.87^{\mathrm{b}}$ & 0.25 & $<0.01$ & 0.42 & 1.97 \\
\hline Isobutyrate $(\mathrm{mmol} / \mathrm{L})$ & $2.45^{\mathrm{a}}$ & $2.49^{\mathrm{a}}$ & $2.97^{\mathrm{ab}}$ & $3.13^{\mathrm{b}}$ & 0.19 & 0.01 & 0.60 & 0.76 \\
\hline Isovalerate $(\mathrm{mmol} / \mathrm{L})$ & $3.07^{\mathrm{a}}$ & $3.32^{\mathrm{a}}$ & $4.06^{\mathrm{b}}$ & $4.26^{\mathrm{b}}$ & 0.18 & $<0.01$ & 0.23 & 0.90 \\
\hline A:P ratio & $3.70^{\mathrm{a}}$ & $2.99^{\mathrm{b}}$ & $3.52^{\mathrm{ab}}$ & $3.50^{\mathrm{ab}}$ & 0.13 & 0.24 & 0.02 & 0.02 \\
\hline
\end{tabular}

F:C ratios, forage-concentrate ratios; SEM, standard error of means; MCP, microbial crude protein; TVFA, total volatile fatty acid.

${ }^{1} \mathrm{HF}+0 \mathrm{mg}=$ high forage $(\mathrm{F}: \mathrm{C}=70: 30)+0 \mathrm{mg}$ gynosaponin; $\mathrm{HF}+16 \mathrm{mg}=$ high-forage $(\mathrm{F}: \mathrm{C}=70: 30)+16 \mathrm{mg}$ gynosaponin; $\mathrm{HC}+0 \mathrm{mg}=$ high-concentrate $(\mathrm{F}: \mathrm{C}=30: 70)+0 \mathrm{mg}$ gynosaponin; $\mathrm{HC}+16 \mathrm{mg}=$ high concentrate $(\mathrm{F}: \mathrm{C}=30: 70)+16 \mathrm{mg}$ gynosaponin.

${ }^{2} \mathrm{~F}: \mathrm{C}=$ effects of forage concentrate ratios; GS = effects of gynosaponin; $\mathrm{F}: \mathrm{C} \times \mathrm{GS}=$ interaction effects of forage concentrate ratios and gynosaponin

a,b,c The means within a row with different superscripts differ significantly $(\mathrm{p}<0.05)$. 


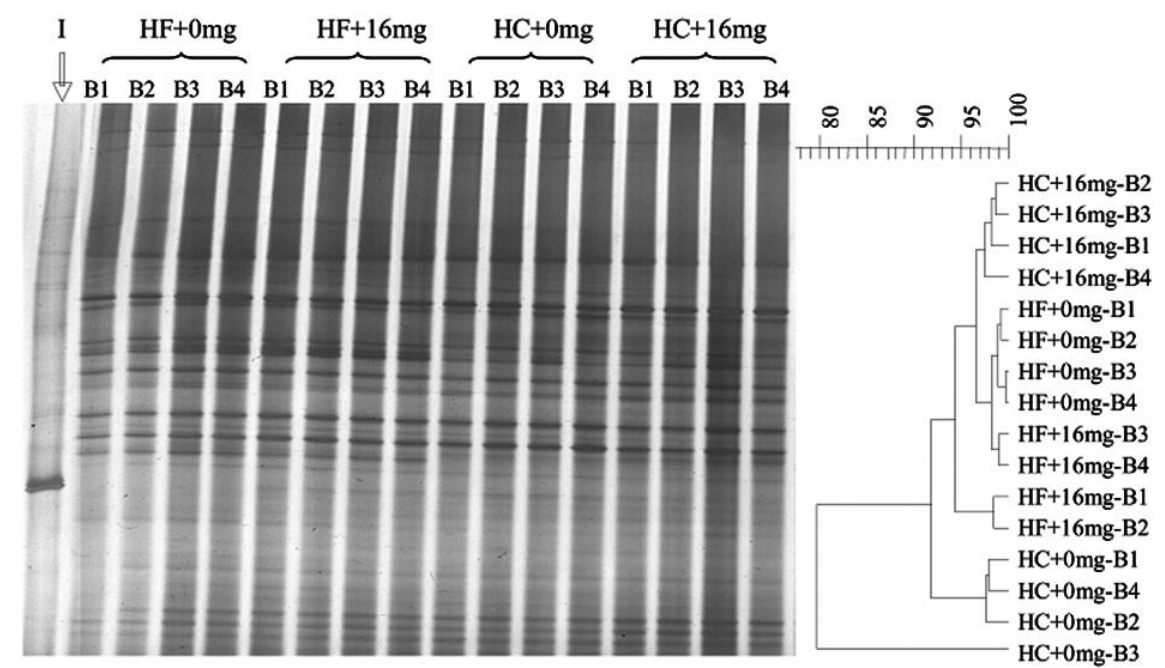

Figure 2. Denaturing gradient gel electrophoresis profile of ruminal bacteria. $\mathrm{HF}+0 \mathrm{mg}=$ high forage $(\mathrm{F}: \mathrm{C}=70: 30)+0 \mathrm{mg}$ gynosaponin; $\mathrm{HF}+16 \mathrm{mg}=$ high-forage $(\mathrm{F}: \mathrm{C}=70: 30)+16 \mathrm{mg}$ gynosaponin; $\mathrm{HC}+0 \mathrm{mg}=$ High-concentrate $(\mathrm{F}: \mathrm{C}=30: 70)+0 \mathrm{mg}$ gynosaponin; HC+16 $\mathrm{mg}=$ High concentrate $(\mathrm{F}: \mathrm{C}=30: 70)+16 \mathrm{mg}$ gynosaponin, $\mathrm{B} 1, \mathrm{~B} 2, \mathrm{~B} 3, \mathrm{~B} 4$; replications .

compared with the high-forage level, under the highconcentrate condition, the $\mathrm{pH}$ value and MCP concentration were lower, whereas concentrations of $\mathrm{NH}_{3}-\mathrm{N}$ and the total and individual VFAs were higher. Gynosaponin treatment increased the $\mathrm{pH}$ in both high and low $\mathrm{F}: \mathrm{C}$ ratios, especially significantly under high-forage condition $(\mathrm{p}<0.05)$, but did not affect the concentrations of $\mathrm{NH}_{3}-\mathrm{N}$ and MCP. Under the high-forage condition, the presence of gynosaponin reduced the acetate concentration $(\mathrm{p}<0.05)$, whereas the propionate concentration slightly increased resulting in a significant reduction of acetate propionate ratio $(\mathrm{p}<0.05)$. Furthermore, the gynosaponin supplementation increased the butyrate concentrations $(\mathrm{p}<0.05)$ in both high and low $\mathrm{F}: \mathrm{C}$ ratios. Except for the butyrate concentration, however, other individual VFA profiles had no changes after treated by gynosaponin under high-concentrate condition.

\section{Rumen microbial communities}

Denaturing gradient gel electrophoresis profiles of bacteria, methanogens and protozoa are shown in Figure 2, 3 , and 4 , respectively. After $48 \mathrm{~h}$ fermentation, in addition to some different bands between two kinds of substrates, no special bands appeared for the composition of total bacteria, protozoa and methanogens after treated by gynosaponin in both high and low $\mathrm{F}$ : $\mathrm{C}$ ratios.

\section{Rumen microbial abundance}

Real-time PCR analysis indicated that (Table 3) variable F:C ratios significantly affected abundances of $F$. succinogenes, $R$. flavefaciens, fungi and counts of protozoa,

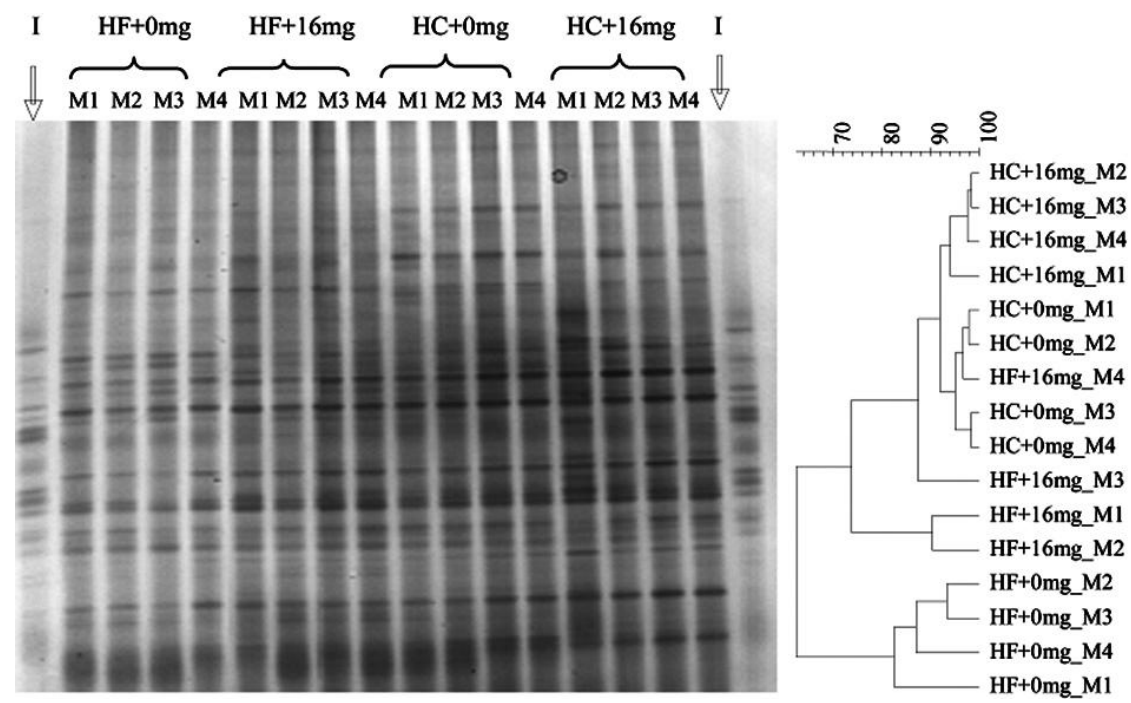

Figure 3. Denaturing gradient gel electrophoresis profile of ruminal methanogens. $\mathrm{HF}+0 \mathrm{mg}=$ high forage $(\mathrm{F}: \mathrm{C}=70: 30)+0 \mathrm{mg}$ gynosaponin; $\mathrm{HF}+16 \mathrm{mg}=$ high-forage $(\mathrm{F}: \mathrm{C}=70: 30)+16 \mathrm{mg}$ gynosaponin; $\mathrm{HC}+0 \mathrm{mg}=$ high-concentrate $(\mathrm{F}: \mathrm{C}=30: 70)+0 \mathrm{mg}$ gynosaponin; $\mathrm{HC}+16 \mathrm{mg}=$ high concentrate $(\mathrm{F}: \mathrm{C}=30: 70)+16 \mathrm{mg}$ gynosaponin. $\mathrm{M} 1, \mathrm{M} 2, \mathrm{M} 3$, M4; replications. 


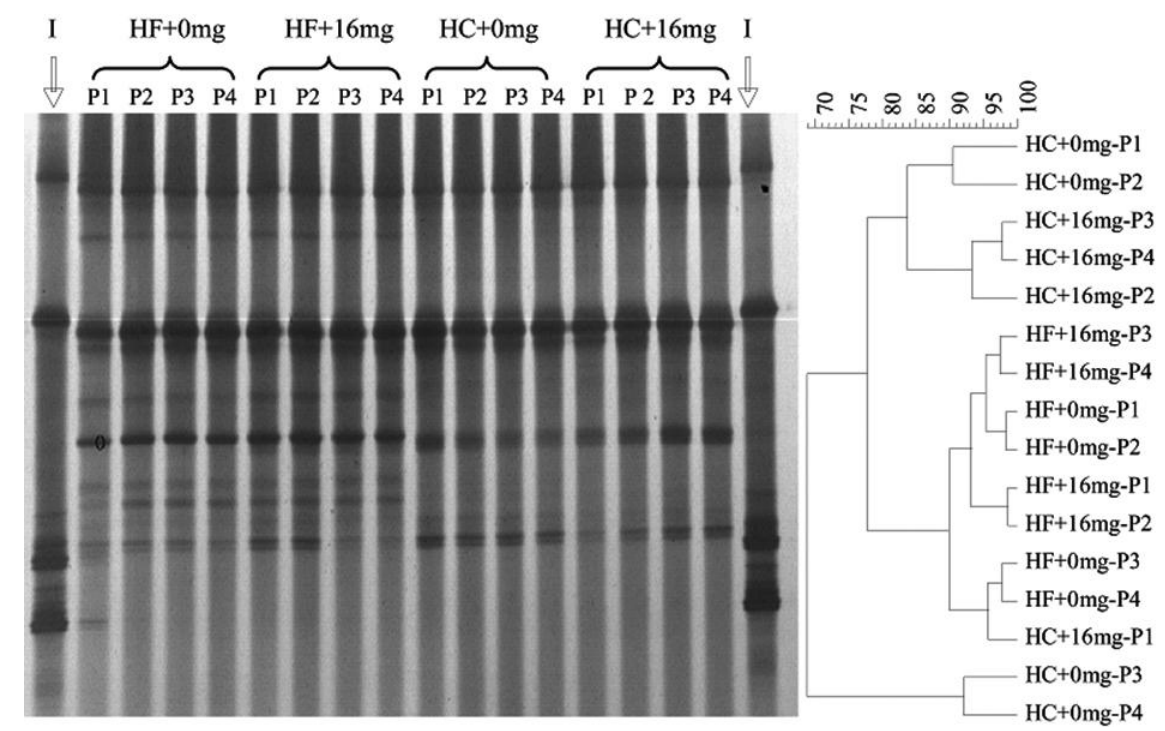

Figure 4. Denaturing gradient gel electrophoresis profile of ruminal protozoa. $\mathrm{HF}+0 \mathrm{mg}=$ high forage $(\mathrm{F}: \mathrm{C}=70: 30)+0 \mathrm{mg}$ gynosaponin; $\mathrm{HF}+16 \mathrm{mg}=$ high-forage $(\mathrm{F}: \mathrm{C}=70: 30)+16 \mathrm{mg}$ gynosaponin; $\mathrm{HC}+0 \mathrm{mg}=$ high-concentrate $(\mathrm{F}: \mathrm{C}=30: 70)+0 \mathrm{mg}$ gynosaponin; HC+16 $\mathrm{mg}=$ high concentrate $(\mathrm{F}: \mathrm{C}=30: 70)+16 \mathrm{mg}$ gynosaponin, $\mathrm{P} 1, \mathrm{P} 2, \mathrm{P} 3, \mathrm{P} 4$; replications.

but did not affect the mcrA gene copies of methangens and abundance of total bacteria. Abundance of $F$. succinogenes and counts of protozoa decreased significantly in highforage substrate after treated by gynosaponin. The supplementation of gynosaponin also slightly reduced the mcrA gene copies of methanogens $(\mathrm{p}<0.10)$ and abundances of total bacteria, fungi and $R$. flavefaciens under high-forage condition. However, addition of gynosaponin under highconcentrate level did not affect the abundances of above microbes.

\section{DISCUSSION}

Total gas production was closely related to the digestion of fermentation substrates and microbial activity and growth. The high total gas production under highconcentrate ratio might be due to the increased activity of related microbes. The reduction of cumulative total gas production with the high-forage substrate during the $48 \mathrm{~h}$ fermentation may be because of the reduced individual gases including methane and VFAs.

Studies have suggested that a high-concentrate diet can modulate the rumen fermentation thereby reducing methane emission. For example, Yan et al. (2000) reported the negative correlation between proportion of concentrate in diet and methane emissions. Similarly, Benchaar et al. (2001) demonstrated that methane production was decreased with the replacement of fibrous concentrate with starchy concentrate by $22 \%$ and with the utilization of less ruminally degradable starch by $17 \%$. Compared with the forage based diets, feeding concentrate based diets lowers the enteric methane emission (Johnson and Johnson, 1995), since starch fermentation promotes propionate production and lowers ruminal $\mathrm{pH}$, thereby inhibits protozoa and methanogens (Williams and Coleman, 1988). Aguerre et al. (2011) reported that increasing the $\mathrm{F}: \mathrm{C}$ ratio increased ruminal $\mathrm{pH}$ and methane production, but had no effect on manure $\mathrm{NH}_{3}-\mathrm{N}$ emission. In our current study however,

Table 3. In vitro effects of gynosaponin on rumen microbial population after $48 \mathrm{~h}$ incubation at different $\mathrm{F}: \mathrm{C}$ ratios

\begin{tabular}{|c|c|c|c|c|c|c|c|c|}
\hline \multirow{2}{*}{ Item (copies/mL) } & \multicolumn{4}{|c|}{ Treatment $^{1}(\mathrm{mg})$} & \multirow{2}{*}{ SEM } & \multicolumn{3}{|c|}{ p-value ${ }^{2}$} \\
\hline & $\mathrm{HF}+0$ & $\mathrm{HF}+16$ & $\mathrm{HC}+0$ & $\mathrm{HC}+16$ & & $\mathrm{~F}: \mathrm{C}$ & GS & $\mathrm{F}: \mathrm{C} \times \mathrm{GS}$ \\
\hline Bacteria $\left(\times 10^{10}\right)$ & 1.37 & 1.27 & 1.23 & 1.23 & 0.05 & 0.08 & 0.30 & 0.31 \\
\hline Methanogen $\left(\times 10^{7}\right)$ & 9.12 & 8.40 & 9.20 & 9.11 & 0.22 & 0.09 & 0.09 & 0.17 \\
\hline Fungi $\left(\times 10^{5}\right)$ & $2.37^{\mathrm{a}}$ & $2.16^{\mathrm{a}}$ & $1.83^{\mathrm{b}}$ & $1.86^{\mathrm{b}}$ & 0.10 & $<0.01$ & 0.19 & 0.12 \\
\hline F. succinogenes $\left(\times 10^{7}\right)$ & $1.04^{\mathrm{a}}$ & $0.86^{\mathrm{b}}$ & $0.38^{\mathrm{c}}$ & $0.29^{c}$ & 0.05 & $<0.01$ & 0.02 & 0.37 \\
\hline R. flavefaciens $\left(\times 10^{7}\right)$ & $2.62^{\mathrm{a}}$ & $2.49^{\mathrm{a}}$ & $1.44^{\mathrm{b}}$ & $1.65^{\mathrm{b}}$ & 0.11 & $<0.01$ & 0.76 & 0.17 \\
\hline Protozoa $\left(\times 10^{3}\right)$ & $8.95^{\mathrm{a}}$ & $7.85^{\mathrm{b}}$ & $6.95^{\mathrm{c}}$ & $6.70^{\mathrm{c}}$ & 0.27 & $<0.01$ & 0.03 & 0.15 \\
\hline
\end{tabular}

$\mathrm{F}: \mathrm{C}$ ratios, forage-concentrate ratios; $\mathrm{SEM}$, standard error of means.

${ }^{1} \mathrm{HF}+0 \mathrm{mg}=$ high forage $(\mathrm{F}: \mathrm{C}=70: 30)+0 \mathrm{mg}$ gynosaponin; $\mathrm{HF}+16 \mathrm{mg}=$ high-forage $(\mathrm{F}: \mathrm{C}=70: 30)+16 \mathrm{mg}$ gynosaponin; $\mathrm{HC}+0 \mathrm{mg}=$ high-concentrate $(\mathrm{F}: \mathrm{C}=30: 70)+0 \mathrm{mg}$ gynosaponin; $\mathrm{HC}+16 \mathrm{mg}=$ high concentrate $(\mathrm{F}: \mathrm{C}=30: 70)+16 \mathrm{mg}$ gynosaponin.

${ }^{3} \mathrm{~F}: \mathrm{C}=$ effects of forage concentrate ratios; GS = effects of gynosaponin; $\mathrm{F}: \mathrm{C} \times \mathrm{GS}=$ interaction effects of forage concentrate ratios and gynosaponin.

a,b,c The means within a row with different superscripts differ significantly $(\mathrm{p}<0.05)$. 
under the high-concentrate level the total gas and methane emission was greater than the high-forage condition. The most likely reason for this was high-concentrate conditions can offer more fermentable substrates for bacteria and methanogens, thus producing more $\mathrm{H}_{2}$ and or formic acid and acetate, leading to more methane, since $\mathrm{H}_{2}$, formic acid and acetate are effective methanogenic substrates (Bauchop and Mountfort, 1981). In addition, in vitro studies though valuable, may not reflect the real activity of diets in the rumen. Indeed, total and individual VFAs were increased with high-concentrate level as compared with high-forage level (Table 2).

The addition of gynosaponin showed no effect on methane production under high concentrate conditions. However, supplementation of gynosaponin inhibited methane production by $14.49 \%$ under high-forage condition. A great many of in vitro researches were conducted to investigate the effects of various saponins on rumen methane production under different $\mathrm{F}$ : $\mathrm{C}$ ratios. Holtshausen et al. (2009) noted that during in vitro $24 \mathrm{~h}$ fermentation Quillaja saponaria $0.75 \mathrm{~g} / \mathrm{L}$ in forage based (F:C = 51:49) substrate decreased the methane production by $11.4 \%$ and Lila et al. (2003) observed that sarsaponin $1.2 \mathrm{~g} / \mathrm{L}$ in forage based $(\mathrm{F}: \mathrm{C}=1.5: 1)$ substrate decreased the methane production by $13.5 \%$. However, Pen et al. (2006) reported that Quillaja saponaria extract $2.3 \mathrm{~g} / \mathrm{L}$ in $\mathrm{F}: \mathrm{C}=1: 1$ substrate did not affect methane production. Goel et al. (2008a) demonstrated that methane suppressing effects of saponins from Sesbenia sesban and fenugreek were pronounced in concentrate-based diets comparing with roughage based diets. All inconsistencies among above the studies about effects of saponins on methane production may have been due to many factors including the types, doses and structures of saponins and composition of diets (Beauchemin et al., 2008).

Microbial protein, $\mathrm{pH}$ value, ammonia-nitrogen and variable VFAs are important rumen inner environmental parameters. In this study, gynosaponin addition increased the $\mathrm{pH}$ value under both high and low $\mathrm{F}$ : $\mathrm{C}$ ratios, especially under high-forage level, but did not affect the MCP and $\mathrm{NH}_{3}-\mathrm{N}$ concentrations. The effects of saponins on rumen $\mathrm{pH}$ values were various, with some studies showing a reduction (Goetsch and Owens, 1985; Wu et al., 1994), while other studies showed an increase (Wang et al., 2011) or no effect (Hussain and Cheeke, 1995; Hristov et al., 1999) after treatment with saponins. Consistent with our study, Hristov et al. (1999) reported that Yucca schidigera extract had no significant effect on microbial protein and Mao et al. (2010) reported that amino-nitrogen concentration was little affected by tea saponin addition.

Coupled with the change of methane emission, our results showed that under a high-forage condition, gynosaponin addition significantly reduced acetate concentration, while slightly increased propionate proportion, thereby resulting in a significant reduction of $\mathrm{A}$ : $P$ ratio. This was in agreement with in vitro observations of Wina et al. (2005) and Staerfl et al. (2010) that the acetate proportion was reduced significantly by Yucca saponins and methanol extract of Sapindus rarak addition respectively. Wang et al. (2011) also found the reduction of acetate concentration after treated by gynosaponin in a fungusmethanogen co-culture system. In addition, consistent with our results, increased propionate concentrations and considerably reduced A:P ratios appeared to be achieved in several in vitro (Lila et al., 2003; Wina et al., 2005; Pen et al., 2006; 2008) studies. Patra et al. (2010) concluded that saponins might increase the propionate production as a result of rechannelling of hydrogen from methane to propionate and decrease the A:P ratio, which is nutritionally beneficial for ruminants. Mao et al. (2010) reported that methane-suppressing effects of saponins could lead to hydrogen accumulation. However, the high partial pressure of hydrogen and high NADH/NAD ${ }^{+}$ratio in the rumen due to the inhibition of methanogenesis may result in a decrease of acetate production (Miller, 1995). Except for the above change in VFA proportions, a slight increase of total VFA concentration was also observed related to the gynosaponin addition under high-forage substrate. Accordingly, the increased $\mathrm{pH}$ value in our study might be due to the reduction of the VFAs concentrations in high-forage level. In addition, increased butyrate concentration of treatment groups in both high and low $\mathrm{F}: \mathrm{C}$ ratios were found in this experiment. But, the mechanism causing the increased butyrate concentration after treated by gynosaponin will need further research.

With DGGE patterns, there were some different bands between two kind substrates, but no special bands appeared for the composition of total bacteria, protozoa and methanogens after treated by gynosaponin in both $\mathrm{F}: \mathrm{C}$ ratios. This may suggest that gynosaponin treatment did not have an affect the microbiota in the rumen. Possibly due to sufficient fibrous materials offered for the fiber degrading microbes, the abundances of $F$. succinogens, $R$. flavefaciens, fungi and counts of protozoa were significantly increased under high-forage conditions as compared with the highconcentrate substrates. Inclusion of gynosaponin in highforage substrate significantly reduced the counts of protozoa and abundance of $F$. succinogenes, also slightly reduced the mcrA gene copies of methanogens and abundances of total bacteria, fungi and $R$. flavefaciens. However, addition of gynosaponin to the high-concentrate level did not affect the abundances of above microbes.

Most studies (Moss et al., 2000; Hu et al., 2005; Goel et al., 2008b) found the methane inhibitory effects of variable 
saponins and these authors contributed this to reduction in protozoa numbers, since protozoa have a symbiotic association with methanogens (Finlay et al., 1994) and methanogens associated with protozoa accounted for as much as $37 \%$ decreased methane production (Bhatta et al., 2009). A strong association of protozoal number and methanogenesis was evident in this experiment and this association seemed to be F:C dependent. Gynosaponin substantially reduced the protozoa numbers and methane production in high-forage substrate, but showed little effect on methane production with high-concentrate substrate. In high-concentrate substrate, protozoa counts were significantly lower than the high-forage condition, thus gynosaponin addition to high-concentrate substrate may not show evident effects on protozoa. In the high-forage substrate however, gynosaponin inhibited the protozoa counts. Thus, it is possible that when protozoa counts were higher, the effect of saponins would be more profound.

Indeed, in our present study methanogens, fungi, $F$. succinogenes and R.flavefaciens were less abundant after treated by gynosaponin under high-forage substrate. Several in vitro studies have reported the direct inhibitory effects of saponins on methanogens. As Goel et al. (2008b) and Wang et al. (2011) noted that saponins significantly reduced methane concentration and inhibited the methanogen growth. Accordant with our results, Wina et al. (2005) observed the toxicity of feeding saponins at high levels occurred to protozoa, fungi and bacteria. Wang et al. (2011) reported that growth of the fungus was decreased by high level gynosaponin addition. Wang et al. (2000) demonstrated that abundances of $F$. succinogenes and $R$. flavefaciens were negatively affected by high level of saponins. Lu and Jorgensen (1987) and Wang et al. (2000) reported that fiber degrading bacteria were more sensitive to saponins than starch degrading bacteria. This may partly explain the current finding that the fibre-degrading bacterial species were evidently affected while the total bacterial population was less affected.

Since Wallace et al. (1994) reported that purified saponins were toxic to rumen microorganisms, the inhibitory effect of gynosaponin on tested microorganisms could be due to its high saponin content as the gynosaponin used in our experiment contained $98 \%$ high saponin purity. Furthermore, Saponins have sterol-binding capability in protozoa and fungi cell membranes (Bodas et al., 2008). Wang et al. (2012) demonstrated that expression of $m c r A$ gene is closely related to the activity of methanogens and methane production. Thus, the slight reduction of mcrA gene copies of methanogens in our study indicates a lowered activity of methanogens. However, the mechanism behind the reduction of methanogens related to saponins is still not yet clear. Further research is needed to elucidate the underlying mechanism.

\section{CONCLUSION}

Gynosaponin supplementation inhibited the rumen in vitro methane production in high-forage conditions by changing fermentation characteristics and the abundance of related microbes.

\section{ACKNOWLEDGMENTS}

This work was supported by the National Natural Science Foundation of China (31072052) and China (MOST) - Australia (IIST) joint project (2010DFA31040). The authors thank Dr Christopher S. McSweeney (CSIRO Livestock Industries, Australia) for providing Methanobrevibacter and Dr Eun Joong Kim (Aberystwyth University, UK) for $R$. flavefaciens and $F$. succinogenes.

\section{CONFLICTS OF INTEREST}

Bakhetgul Manatbay conducted animal experiment, performed DGGE and q-PCR, analyzed the data and drafted the manuscript. Yanfen Cheng helped with methane measurement, DGGE and q-PCR. Shengyong Mao helped with experiment design and statistical analysis. Weiyun Zhu conceived this study, finalized the manuscript and revised the manuscript. We certify that there is no conflict of interest with any financial organization regarding the material discussed in the manuscript.

\section{REFERENCES}

Aguerre, M. J., M. A. Wattiaux, J. M. Powell, G. A. Broderick, and C. Arndt. 2011. Effect of forage to concentrate ratio in dairy cow diets on emission of methane, carbon dioxide, and ammonia, lactation performance, and manure excretion. J. Dairy Sci. 94:3081-3039.

Bauchop, T. and D. O. Mountfort. 1981. Cellulose fermentation by a rumen anaerobic fungus in both the absence and the presence of rumen methanogens. Appl. Environ. Microbiol. 42:11031110 .

Beauchemin, K., M. Kreuzer, F. O'mara, and T. McAllister. 2008. Nutritional management for enteric methane abatement: A review. Anim. Prod. Sci. 48:21-27.

Benchaar, C., C. Pomar and J. Chiquette. 2001. Evaluation of dietary strategies to reduce methane producion in ruminants: A modelling approach. Can. J. Anim. Sci. 81:563-574.

Bhatta, R., Y. Uyeno, K. Tajima, A. Takenaka, Y. Yabumoto, I. Nonaka, O. Enishi, and M. Kurihara. 2009. Difference in the nature of tannins on in vitro ruminal methane and volatile fatty acid production and on methanogenic archaea and protozoal populations. J. Dairy Sci. 92:5512-5522.

Blumer, M. and J. L. Liu. 1999. Jiaogulan in China's "Immortalit Herb", Torchlight Pubishing Inc., Badger, USA. 
Bodas, R., S. López, M. Fernández, R. García-González, A. B. Rodríguez, R. J. Wallace, and J. S. González. 2008. In vitro screening of the potential of numerous plant species as antimethanogenic feed additives for ruminants. Anim Feed Sci Technol. 145:245-258

Cheng, Y. F., S. Y. Mao, C. X. Pei, J. X. Liu, and W. Y. Zhu. 2006. Detection and diversity analysis of rumen methanogens in the co-cultures with anaerobic fungi. Acta Microbiol. Sin. 46:879883

Dehority, B. A. 2005. Ciliate protozoa. In: Methods in Gut Microbial Ecology for Ruminants (Eds. H. P. S. Makkar, and C. S. McSweeney). IAEA, Netherlands. pp. 67-78.

Denman, S. E. and C. S. McSweeney. 2006. Development of a real-time PCR assay for monitoring anaerobic fungal and cellulolytic bacterial populations within the rumen. FEMS Microbiol. Ecol. 58:572-582.

Denman, S. E., N. W. Tomkins, and C. S. McSweeney. 2007. Quantitation and diversity analysis of ruminal methanogenic populations in response to the antimethanogenic compound bromochloromethane. FEMS Microbiol. Ecol. 62:313-322.

Finlay, B. J., G. Esteban, K. J. Clarke, A. G. Williams, T. M. Embley and R. P. Hirt. 1994. Some rumen ciliates have endosymbiotic methanogens. FEMS Microbiol. Lett. 117:157161.

Goel, G., H. P. S. Makkar, and K. Becker. 2008a. Effect of Sesbania sesban and Carduus pycnocephalus leaves and fenugreek seeds (Trigonella foenum-graecum L.) and their extracts on partitioning of nutrient from roughage and concentrate based feeds to methane. Anim. Feed Sci. Technol. 147:72-89.

Goel, G., H. P. Makkar, and K. Becker. 2008b. Changes in microbial community structure, methanogenesis and rumen fermentation in response to saponin-rich fractions from different plant materials. J. Appl. Microbiol. 105:770-777.

Goetsch, A. L. and F. N. Owens. 1985. Effects of sarsaponin on digestion and passage rates in cattle fed medium to low concentrate. J. Dairy Sci. 68:2377-2384.

Guo, Y. Q., J. X. Liu, Y. Lu, W. Y. Zhu, S. E. Denman, and C. S. McSweeney. 2008. Effect of tea saponin on methanogenesis, microbial community structure and expression of mcrA gene, in cultures of rumen micro-organisms. Lett. Appl. Microbiol. 47:421-426

Hassan, S. M., J. A. Byrd, A. L. Cartwright, and C. A. Bailey. 2010. Hemolytic and antimicrobial activities differ among saponinrich extracts from guar, quillaja, yucca, and soybean. Appl. Biochem. Biotechnol. 162:1008-1017.

Holtshausen, L., A. V. Chaves, K. A. Beauchemin, S. M. McGinn, T. A. McAllister, N. E. Odongo, P. R. Cheeke, and C. Benchaar. 2009. Feeding saponin-containing Yucca schidigera and Quillaja saponaria to decrease enteric methane production in dairy cows. J. Dairy Sci. 92:2809-2821.

Hristov, A. N., T. A. McAllister, F. H. Van Herk, K. J. Cheng, C. J. Newbold, and P. R. Cheeke. 1999. Effect of Yucca schidigera on ruminal fermentation and nutrient digestion in heifers. $\mathrm{J}$ Anim. Sci. 77:2554-2563.

Hu, W. L., J. X. Liu, J. A. Ye, Y. M. Wu, and Y. Q. Guo. 2005. Effect of tea saponin on rumen fermentation in vitro. Anim Feed Sci Technol. 120:333-339.

Hussain, I. and P. R. Cheeke. 1995. Effect of dietary Yucca
Schidigera extract on rumen and blood profiles of steers fed concentrate-or roughage-based diets. Anim. Feed Sci Technol. 51:231-242.

Johnson, K. A. and D. E. Johnson. 1995. Methane emissions from cattle. J. Anim Sci. 73:2483-2492.

Kuwahara, M., F. Kawanishi, T. Komiya, and H. Oshio. 1989. Dammarane saponins of Gynostemma pentaphylum Makino and isolation of malonylginsenosides- $R b_{1}, \quad-R d$, and malonylgypenoside V. Chem. Pharm. Bull. 37:135-139.

Lila, Z. A., N. Mohammed, S. Kanda, T. Kamada, and H. Itabashi. 2003. Effect of sarsaponin on ruminal fermentation with particular reference to methane production in vitro. J. Dairy Sci. 86:3330-3336.

Longland, A. C., M. K. Theodorou, R. Sanderson, S. J. Lister, C. J. Powell, and P. Morris. 1995. Non-starch polysaccharide composition and in vitro fermentability of tropical forage legumes varying in phenolic content. Anim. Feed Sci Technol. 55:161-177.

Lu, C. D. and N. A. Jorgensen. 1987. Alfalfa saponins affect site and extent of nutrient digestion in ruminants. J. Nutr. 117:919927.

Makkar, H. P., O. P. Sharma, R. K. Dawra, and S. S. Negi. 1982. Simple determination of microbial protein in rumen liquor. $\mathrm{J}$ Dairy Sci. 65:2170-2173.

Mao, H. L., J. K. Wang, Y. Y. Zhou, and J. X. Liu. 2010. Effects of addition of tea saponins and soybean oil on methane production, fermentation and microbial population in the rumen of growing lambs. Livest. Sci. 129:56-62.

Mao, S. Y., W. Y. Zhu, Q. J. Wang, and W. Yao. 2007a. Effect of daidzein on in vitro fermentation of micro-organisms from the goat rumen. Anim. Feed Sci. Technol. 136:154-163.

Mao, S. Y., G. Zhang, and W. Y. Zhu. 2007b. Effect of disodium fumarate on in vitro rumen fermentation of different substrates and rumen bacterial communities as revealed by denaturing gradient gel electrophoresis analysis of $16 \mathrm{~S}$ ribosomal DNA. Asian Australas. J. Anim. Sci. 20:543-549.

Miller, T. L. 1995. Ecology of methane production and hydrogen sinks in the rumen. In: Ruminant Physiology: Digestion, Metabolism, Growth and Reproduction (Eds. W. Engelhardt, S. Leonhard-Marek, G. Breves, D. Giesecke, and V. Ferdinand Enke). Stuttgart, Germany. pp. 317-331.

Moss, A. R., J. P. Jouany, and J. Newbold, 2000. Methane production by ruminants: its contribution to global warming. Ann. Zootech. pp. 49:231-253.

Muyzer, G., E. C. de Waal, and A. G. Uitterlinden. 1993. Profiling of complex microbial populations by denaturing gradient gel electrophoresis analysis of polymerase chain reactionamplified genes coding for 16S rRNA. Appl. Environ. Microbiol. 59:695-700.

Patra, A., D. Kamra, and N. Agarwal. 2006. Effect of plant extracts on in vitro methanogenesis, enzyme activities and fermentation of feed in rumen liquor of buffalo. Anim. Feed Sci. Technol. 128:276-291

Patra, A. K., D. N. Kamra, and N. Agarwal. 2010. Effects of extracts of spices on rumen methanogenesis, enzyme activities and fermentation of feeds in vitro. J. Sci. Food Agric. 90:511520

Pen, B., C. Sar, B. Mwenya, K. Kuwaki, R. Morikawa, and J. Takahashi. 2006. Effects of Yucca schidigera and Quillaja 
saponaria extracts on in vitro ruminal fermentation and methane emission. Anim. Feed Sci. Technol. 129:175-186.

Pen, B., C. Sar, B. Mwenya, and J. Takahashi. 2008. Effects of Quillaja saponaria extract alone or in combination with Yucca schidigera extract on ruminal fermentation and methanogenesis in vitro. Anim. Sci J. 79:193-199.

Staerfl, S. M., M. Kreuzer, and C. R. Soliva. 2010. In vitro screening of unconventional feeds and various natural supplements for their ruminal methane mitigation potential when included in a maize-silage based diet. J Anim Feed Sci. 19:651-664.

Sylvester, J. T., S. K. R. Karnati, Z. Yu, C. J. Newbold, and J. L. Firkins. 2005. Evaluation of a real-time PCR assay quantifying the ruminal pool size and duodenal flow of protozoal nitrogen. J. Dairy Sci. 88:2083-2095.

Tanner, M. A., X. Bu, J. A. Steimle, and P. R. Myers. 1999. The direct release of nitric oxide by gypenoside derived from the herb Gynostemma pentaphyllm. Nitric Oxide 3:359-365.

Theodorou, M. K., B. A. Williams, M. S. Dhanoa, A. B. McAllan, and J. France. 1994. A simple gas production method using a pressure transducer to determine the fermentation kinetics of ruminant feeds. Anim Feed Sci. Technol. 48:185-197.

Vincken, J. P., L. Heng, A. de Groot, and H. Gruppen. 2007. Saponins, classification and occurrence in the plant kingdom. Phytochemistry 68:275-297.

Wallace, R. J., L. Arthaud, and C. J. Newbold. 1994. Influence of Yucca shidigera extract on ruminal ammonia concentrations and ruminal microorganisms. Appl. Environ. Microbiol. 60:1762-1767.

Wang, J. K., J. A. Ye, and J. X. Liu. 2012. Effects of tea saponins on rumen microbiota, rumen fermentation, methane production and growth performance-A review. Trop. Anim. Health Prod. 44:697-706

Wang, X., S. Mao, J. Liu, L. Zhang, Y. Cheng, W. Jin, and W. Zhu. 2011. Effect of gynosaponins on methane production and microbe numbers in a fungus-methanogen co-culture. J. Anim. Feed Sci. 20:272-284.
Wang, Y., T. A. McAllister, L. J. Yanke, and P. R. Cheeke. 2000. Effect of steroidal saponin from Yucca schidigera extract on ruminal microbes. J. Appl. Microbiol. 88:887-896.

Weatherburn, M. 1967. Phenol-hypochlorite reaction for determination of ammonia. Anal. Chem. 39:971-974.

Williams, A. G. and G. S. Coleman. 1988. The rumen protozoa. In: The Rumen Microbial Ecosystem (Eds. P. N. Hobson and C. S. Stewart). Springer, New York, USA. pp. 77-129.

Wina, E., S. Muetzel, E. Hoffmann, H. Makkar, and K. Becker. 2005. Saponins containing methanol extract of Sapindus rarak affect microbial fermentation, microbial activity and microbial community structure in vitro. Anim. Feed Sci. Technol. 121:159-174.

Wu, Z., M. Sadik, F. T. Sleiman, J. M. Simas, M. Pessarakli, and J. T. Huber. 1994. Influence of yucca extract on ruminal metabolism in cows. J. Anim. Sci. 72:1038-1042.

Yang, C. J., S. Y. Mao, L. M. Long, and W. Y. Zhu. 2012. Effect of disodium fumarate on microbial abundance, ruminal fermentation and methane emission in goats under different forage: concentrate ratios. Animal 6:1788-1794.

Yan, T., R. Agnew, F. Gordon, and M. Porter. 2000. Prediction of methane energy output in dairy and beef cattle offered grass silage-based diets. Livest Prod. Sci. 64:253-263.

Yu, Z., R. Garcia-Gonzalez, L. Floyd, Schanbacher, and M. Morrison. 2008. Evaluations of different hypervariable regions of archaeal 16S rRNA genes in profiling of methanogens denaturing by Archaea-specific PCR and gradient gel electrophoresis. Appl. Environm. Microbiol. 74:889-893

Zhu, W. Y., A. H. Kingston-Smith, D. Troncoso, R. J. Merry, D. R. Davies, G. Pichard, H. Thomas, and M. K. Theodorou. 1999. Evidence of a role for plant proteases in the degradation of herbage proteins in the rumen of grazing cattle. J. Dairy Sci. 82:2651-2658.

Zhu, W. Y., B. A. Williams, S. R. Konstantinov, S. Tamminga, W. M. de Vos, and A. D. L. Akkermans. 2003. Analysis of $16 \mathrm{~S}$ rDNA reveals bacterial shift during in vitro fermentation of fermentable carbohydrate using piglet faeces as inoculum. Anaerobe 9:175-180. 